\title{
CROSS-CULTURAL COMPARISON OF TEACHERS' ATTITUDES TOWARD EDUCATIONAL RESEARCH: THE CASE OF TURKEY AND KOSOVO
}

\author{
Assoc. Prof. Dr. Mustafa ÖZGENEL (iD) 1* \\ Esin METLİLO (iD) 2 \\ 1 Istanbul Sabahattin Zaim University, Faculty of Education, mustafa.ozgenel@izu.edu.tr *Correspondent Author. \\ 2 Istanbul Sabahattin Zaim University, Educational Management PhD Stud, esin.metlilo@std.izu.edu.tr
}

\author{
Article history: \\ Submission 24 December 2020 \\ Revision 20 January 2021 \\ Accepted 10 March 2021 \\ Available online 30 April 2021
}

\section{Keywords: \\ Teacher Attitude, \\ Educational Research, \\ Cross-Cultural Comparison.}

DOI:

https://doi.org/10.32936/pssi.v5i1.215

\begin{abstract}
A b s t r a c t
This study aims to a cross-cultural comparison of teachers' attitudes towards educational research in Turkey and Kosovo. The study is carried out according to the descriptive survey model, which is one of the quantitative research models. The study group consists of a total of 336 teachers 186 teachers from Turkey (Istanbul and Batman) and 150 teachers from Kosovo (Prizren) working in the academic year of 2018-2019. As a data collection tool, "Teacher Attitude Scale for Educational Research" and "Personal Information Form" is used to determine the demographic characteristics of teachers. The data is analyzed with the SPSS statistics program. The data is analyzed by independent groups't-test and one-way analysis of variance. According to the findings, it is revealed that in Turkey, the teachers' attitudes towards educational research are "high level", while in Kosovo, teachers' attitudes towards educational research are "moderate level". Moreover, as a result of cross-cultural comparisons, a significant difference is discovered between teachers' attitudes towards educational research. It is determined that this significant difference is in the subdimensions of the necessity of educational research and the applicability of educational research.
\end{abstract}

\section{Introduction}

Education is expressed as the biggest factor in an individual's learning and a lifelong process (Aydın, 2016). Education is an effect of society on current and future generations (Gökalp, 1992). Education is a training process that progresses on certain goals (Fidan and Erden, 1986).

Education is the biggest investment in behavior change to the human self and personality (Ertürk, 1994). According to Littre, education it the type of mind or skills acquired and the whole of developing moral qualities. According to Stuart Mill, education is a culture that is transferred from generation to generation and gained by preserving and increasing the development stage reached (Cited in Bilhan, 1994). Education exists to acquire knowledge and skills that will take a long time when the individual acquires on their own in a very short time (Başaran, 1994). Education is an essential element in meeting people's needs throughout their lives. Each society has specific goals and ideals for the education system (Aydın, 2016). The goals and ideals differ from society to society, from country to country.
Schools act as institutions to achieve these goals. The technical basis of schools goes through teaching and learning (Hoy and Miskel, 2015). The most important factor that ensures the existence of the school is the educational need of the society and the individual. School is a social system with different roles and statuses. In general terms, the school, in a certain place, in a certain time period, appeals to a wide environment, carries out planned and programmed educational activities has vocational and religious types (Boehm, 1982), teaches community culture to children and young people, are educational institutions that are tasked with acquiring certain knowledge and skills according to their abilities (Ergün, 1994).

The teacher is the teacher of the students as a member of the class and as an individual. The teacher is an education leader for his students. The teacher is a guide that guides students' learning. The first thing to do in this process is to determine learning goals and to guide students in line with these goals (Hattie, 2012). Teachers should continuously improve their professional knowledge and skills to offer effective learning to their students 
and keep them open to learning (Sarı, 2006; Şahin and Arcagök, 2013). The teacher should update knowledge and skills in the subject area by participating in lifelong learning. How can teachers and educators access the information they need? Of course, there are multiple ways to access information. The most accurate and reliable way to access information is through science (Fraenkel and Wallen, 2006).

Science is knowing the universe and finding the truth. Principles in science, research, publications, and academic fields are among the subjects that should be carefully considered. Science is defined as a systematic collection of information that has been systematically obtained and validated to meet certain social needs (Can, 2014). Science tries to produce consistent, stable, reliable, and valid information. The most reliable aspect of accessing scientific information is a scientific research (Aydın, 2016, p. 138). The scientific research process, which starts with the existence of the problem, includes defining the problem, choosing the method, collecting data, processing the data, results, and solutions based on these results (Büyüköztürk et al., 2014). Scientific research is the function of understanding the characteristics of the society, unraveling the profiles of people, revealing the variables in the dimension of relationships, analyzing the causes that affect the occurrence of problems from different aspects and also producing scientific information (Özdamar, 2003). Scientific research adds new knowledge to existing knowledge in scientific literature. There is accumulation and continuity in scientific research. Each research is in a sense a continuation of the previous ones. Based on the results of scientific research, it adds knowledge in the field (Yıldırım and Şimşek, 2018). The methods used in scientific research help us learn that there are no limits in world knowledge and that there is more information that can learn infinitely and always (Stacey, 1969).

The scientific method is an operational and intellectual process. The scientific method covers the methods of description and explanation that sciences use jointly. Educational research is the study of educational problems with the help of scientific methods. Educational research investigates different events and phenomena that take place during the educational process. Educational research aims to improve the quality of education (Everton et al., 2012). Educational research tries to find solutions to the problems felt in education. The teachers who follow the educational research also follow the contemporary education process worldwide (Drill et al., 2012). Therefore, each teacher must follow recent educational research as a researcher identity (Cohen et al., 2007; Sar1, 2006; Zeulli, 1994). In order to fulfill this requirement, they should be able to carry their research results to their fields of study and carry out the application based on their professional experience (Şahin and Arcagök, 2013). Especially our century has aimed to develop teachers with these features (Hoshmand, 1991). However, the extent to which educational researches that concerns teachers the most reaches teachers in schools, how much these researches are made on a scientific scale, and who the recommendations are taken into consideration (Hannesssy and Lunch, 2013). The level of teachers' benefiting from educational research is related to the teacher's attitude towards research (Kara, 2017; Muthuswamy et al., 2017).

It can be said that there is a judgment or prejudice created by people against the events, objects, and facts taking place around us. According to Plotnik (2009), attitude includes an object, an individual or an assessment of the event and leads the individual to a certain behavior. According to Demirel (2003), attitude is the tendency that leads people to show certain actions and behaviors towards certain individuals, objects, and events. According to Morgan (2013), individuals' attitudes develop in the process of socialization based on their personal knowledge and experience. Attitude, which is one of the personal characteristics of the individual, can be defined as the tendency to act in a certain way against the situations that the individual faces and the state of mental readiness (Marshall, 1999). Attitudes consist of three closely related elements. These are effective (emotions towards an object), behavioral (behavioral tendency, intentions, and behavioral expectations) and cognitive (belief and knowledge). For example, if the individual has positive feelings towards a person, possibly behavioral and cognitive tendencies also favorably support their attitude (Petty et al., 2003). As seen in definitions, attitude can vary from person to person, from event to event. Considering that teacher attitudes towards educational research are in such a process of change, it can be stated that educational research may differ and contribute in terms of improving teachers' educational practices.

Scientific research, which follows and examines change and developments contributes greatly to education. Researches in education provide convenience to teachers within the scope of applications. Worldwide research may be applicable in our country. Therefore, scientific research in every field of education is important for our society. It is possible to bring successful individuals to society, to follow innovations, to update the information and to obtain useful information in the changing technology world. This is related to the positive attitudes of teachers towards educational research by developing researcher identity (Auger and Wideman, 2000). Positive attitudes towards scientific-educational research are the key to success in resolving problems quickly (Nagra and Kaur, 2013) and in the dimension 
of progress for the societies that underpin knowledge (Butt and Shams, 2013).

Isakson and Ellwort (1978) think that educational research findings will lead to the development of classroom practice. However, there are differences between conducting educational research, publishing their findings, and applying them in the classroom. In order to determine the causes of this situation, first of all, teachers' findings against educational research should be determined (Johnson, 1966). In other words, although there are differences between the findings obtained from the researches and the implementation of these findings, there are some limitations and difficulties in the application. For this reason, it is considered valuable to transfer the findings obtained from educational research into educational practices and to determine the attitudes of teachers towards educational research in order to reduce the gap between research and practice (Linden et al., 2015). If the teachers value educational researches, believe in its necessity, and show a positive view in terms of its applicability, then it can be said that the research carried out is valuable and important, and also contributes to educational practices. It is thought that comparing the attitudes of teachers towards educational research between cultures will contribute to educational practices and professional development of teachers evaluating themselves in terms of cultural differences. In this sense, the aim of the research is to examine the cross-cultural comparison of teachers' attitudes towards educational research. In line with the general purpose of the study, answers to the following questions were sought:

$\checkmark \quad$ What is the level of education of teachers' attitudes towards educational research in Turkey and Kosovo? $\checkmark \quad$ Do attitudes of teachers in Turkey and Kosovo towards educational research differ significantly according to cross-cultural comparison?

$\checkmark$ Do attitudes of teachers in Turkey and Kosovo towards educational research differ significantly according to their gender, age, educational level, occupational seniority, departments that they graduated from, and levels of schools that they are working in?

\section{Methodology}

\subsection{Research Model}

The research is carried out according to the survey model, which is frequently used in quantitative research methods. The survey model is often preferred in educational research because of its versatility, efficiency, and generalizability (McMillian and Schumacher, 2006). The survey model is a quantitative survey pattern in which we apply a questionnaire or questionnaire to a group of people to describe the general tendencies, attitudes, opinions, behaviors, or characteristic features of people's behavior (Creswell, 2017).

\subsection{Study Group}

Study group of the research composed of a total of 336 teachers. 186 of these teachers were working in Turkey's Istanbul and Batman provinces in the 2018-2019 academic year in state's primary, secondary, and high schools. 150 of these teachers were working in Kosovo, Prizren in the same academic year and school levels. The frequency and percentage distributions of the teachers participating in the research regarding the variables of culture, gender, age, education level, occupational seniority, department, and school type are given in Table 1 . 
Table 1. Demographic features of teachers

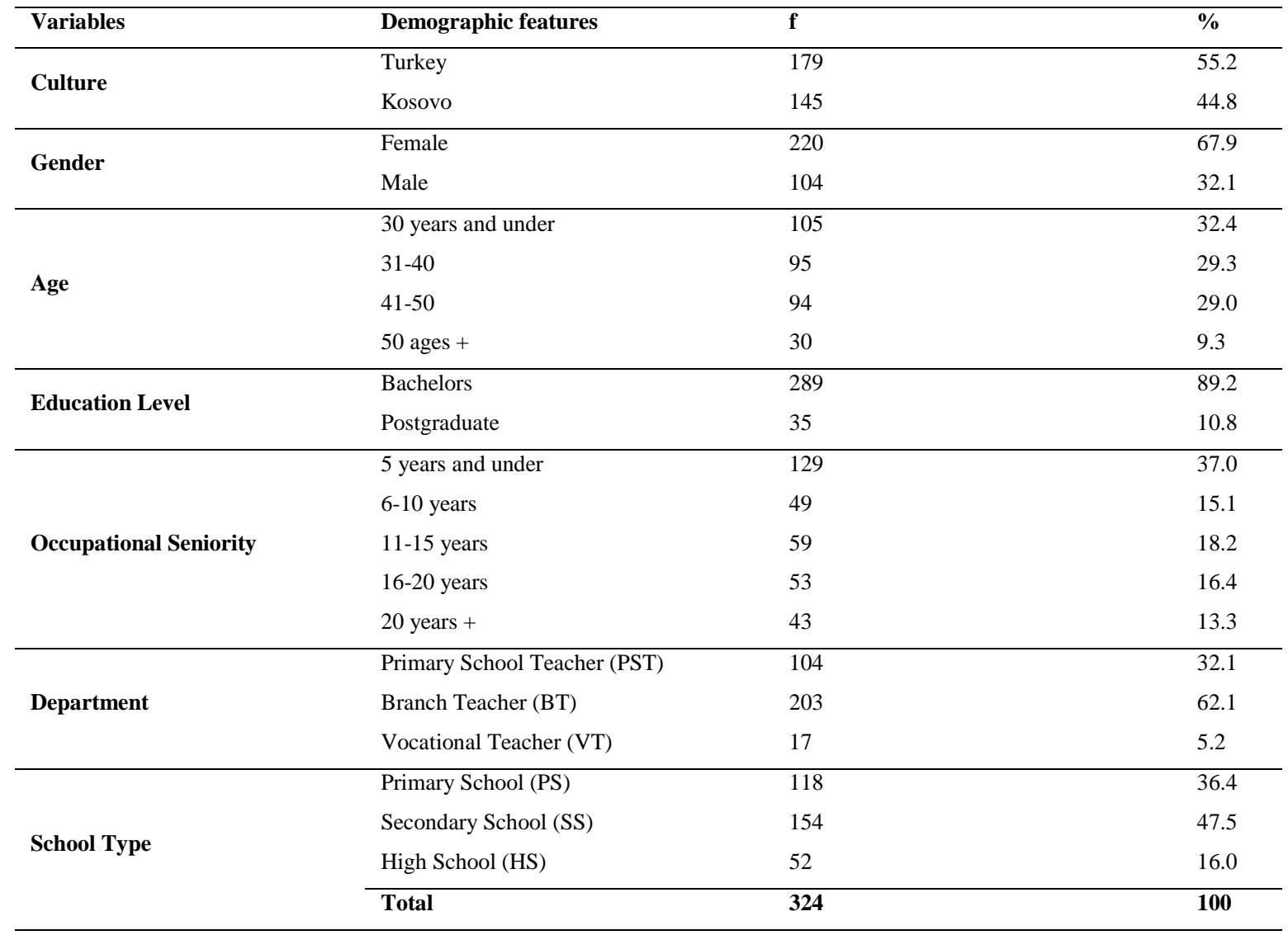

As is seen in Table 1, \%55.2 of the teachers who participated in research constitutes from teachers provide training in Turkey, while $\% 44.8$ of the teachers constitutes from teachers in Kosovo. $67.9 \%$ of the teachers participating in the research are women and $32.1 \%$ are men. Accordingly, a higher number of female teachers indicates that the teaching profession is highly preferred by women. $32.4 \%$ of the teachers participating in the study are between the ages of $20-30,29.3 \%$ between the ages of $31-40$, $29.0 \%$ between the ages of $41-50$ and $9.3 \%$ between the ages of 50 and over. Accordingly, we can state that the majority of teachers are between the ages of 20-30 and that the teachers consist of young staff. The vast majority $(89.2 \%)$ of the teachers participating in the research have only a bachelor's degree. The highest percentage value $(37.0 \%)$ of the teachers participating in the research in terms of professional seniority variable is in the range of $1-5$ years. The majority of teachers $(62.1 \%)$ participating in the research are branch teachers. According to the type of school variable, the majority of teachers $(47.5 \%)$ are teachers who give education in secondary school. It shows that the majority of the teachers who participated in our research and who voluntarily agreed to answer our scale consisted of only teachers with bachelor's degrees, giving education in the branch, secondary school and who have professional seniority in the range of 1-5 years.

\subsection{Data Collection Tool}

In comparing the attitudes of the teachers participating in the research towards educational researches across cultures, "Teachers Attitude Scale Towards Educational Research (TASTER) developed by İlhan et al., (2013) and "Personal Information Form" prepared by the researchers to determine the demographic characteristics of the teachers are used. The fivepoint Likert type "Teacher Attitude Scale Towards Educational Research" [TASTER] was developed by İlhan et al. The scale consists of three sub-dimensions and twenty items. Subdimensions Necessity of Educational Research [NER] (E1, E3, E7, E10, E14, E17, E20), Valuing Educational Research [VER] (E2, E6, E9, E11, E12, E16) and Applicability of Educational Research [APER] (E4, E5, E8, E13, E15, E18, E19). The Cronbach Alpha coefficient of the scale was 0.81 , and the Cronbach Alpha coefficient is calculated as 0.69 in this study. In the "Personal Information Form", variables related to the teachers' gender, age, education level, professional seniority, the department they graduated from and the institution they work in are included.

\subsection{Analysis of Data}

In the study, the data is analyzed with the SPSS statistics program. Frequency, percentage, standard deviation, and arithmetic mean values related to the data were found. Extreme values that are not 
normally distributed have been omitted. The number of data has decreased to 324 due to the extreme values removed. In order to determine whether there is a significant difference in the evaluation of quantitative data, t-test in binary variables, one-way analysis of variance in more than two variables, and Post-Hoc tests were performed to find the source of the difference.

\section{Findings}

The average and standard deviation values of teachers' attitudes towards educational researches are given in Table 2.

Table 2. Arithmetic means and standard deviation regarding the levels of teachers' attitudes towards educational research

\begin{tabular}{|c|c|c|c|c|}
\hline Turkey & $\mathbf{N}$ & Mean & Sd & Evaluation \\
\hline The necessity of educational research (NER) & 179 & 4,06 & 421 & High \\
\hline Valuing educational research (VER) & 179 & 4,27 & 432 & Very High \\
\hline Applicability of educational research (APER) & 179 & 2,87 & ,755 & Moderate \\
\hline Teacher Attitude Scale Toward Educational Research (TASTER) & 179 & 3,71 & 282 & High \\
\hline Kosovo & $\mathbf{N}$ & Mean & Sd & Evaluation \\
\hline The necessity of educational research (NER) & 145 & 4,17 & 417 & High \\
\hline Valuing educational research (VER) & 145 & 4,36 & 479 & Very High \\
\hline Applicability of educational research (APER) & 145 & 2,66 & ,701 & Moderate \\
\hline Teacher Attitude Scale Toward Educational Research (TASTER) & 145 & 3,70 & 296 & High \\
\hline
\end{tabular}

As seen in Table 2 teachers' attitudes towards the necessity of educational research in Turkey and Kosovo "high" level ( $\mathrm{M}=4.06 ; \mathrm{M}=4.17)$; their attitudes towards valuing educational research are "very high" $(\mathrm{M}=4.27$; $\mathrm{M}=4.36)$; their attitudes towards the applicability of educational research are at the "moderate" level (M=2.87; M=2.66) and their attitudes towards educational research in general are at the "high" level $(M=3.71$; $\mathrm{M}=3.70)$.

The results of the t-test analysis conducted to determine the cultural difference of teachers are given in Table 3 .

Table 3. T-test analysis results for cross-cultural comparison of teachers' attitudes towards educational research

\begin{tabular}{llcccccc}
\hline Sub-dimensions & Culture & N & M & Sd & df & t & p \\
\hline \multirow{2}{*}{ NER } & Turkey & 179 & 4.06 & .42 & 322 & -2.33 & $\mathbf{. 0 2 0}$ \\
& Kosovo & 145 & 4.17 & .41 & & & \\
\hline \multirow{2}{*}{ VER } & Turkey & 179 & 4.27 & .43 & \multirow{2}{*}{322} & -1.76 & .078 \\
& Kosovo & 145 & 4.36 & .47 & & & \\
\hline \multirow{2}{*}{ APER } & Turkey & 179 & 2.87 & .75 & 322 & \multirow{2}{*}{2.55} & \multirow{2}{*}{$\mathbf{0 1 1}$} \\
& Kosovo & 145 & 2.66 & .70 & & & \\
\hline \multirow{2}{*}{ TASTER } & Turkey & 179 & 3.71 & .28 & \multirow{2}{*}{322} & .24 & .811 \\
& Kosovo & 145 & 3.70 & .29 & & & \\
\hline
\end{tabular}

As can be seen in Table 3, according to the results of the t-test analysis carried out regarding the cross-cultural comparison of teachers' attitudes towards educational research there are no significant differences can be detected on valuing on educational research and attitude toward educational research in general in both countries $(p>.05)$. Their attitudes towards the necessity of research and applicability of educational research differ significantly $(\mathrm{p}>.05)$. Teachers' attitudes toward the necessity of educational research in Kosovo $(M=4.17)$ are higher than teachers' attitudes toward the necessity of educational research in Turkey $(\mathrm{M}=4.06)$. However, teachers' attitudes towards the applicability of educational research in Turkey $(\mathrm{M}=2.87)$ are higher than teachers' attitudes towards the applicability of educational research in Kosovo (M=2.66).

In comparing the attitudes of teachers towards educational research across cultures, t-test analysis results according to gender variables are given in Table 4. 
Table 4. Results of t-test analysis regarding gender variable in comparing teachers' attitudes towards education research across cultures

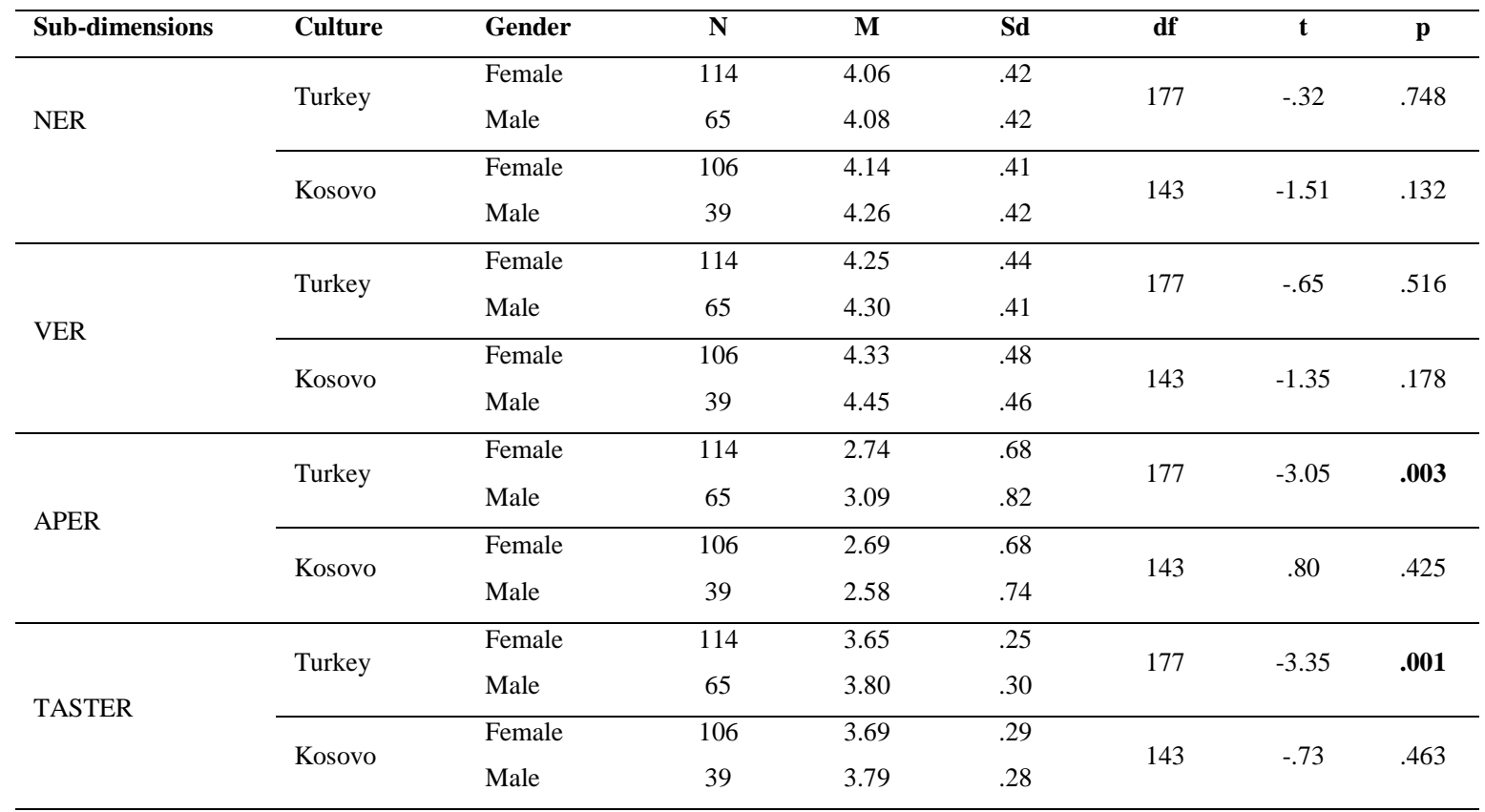

As Table 4 shows, according to the results of the t-test analysis carried out regarding the cross-cultural comparison of teachers' attitudes towards educational researches on the gender variable, there are no significant differences can be detected on valuing on educational researches and attitude toward educational research in general in both countries ( $p>.05)$. However, the applicability of educational researches $(\mathrm{t}=-3.05 ; \mathrm{p}<.05)$, and the attitude towards educational researches in general $(\mathrm{t}=-.73 ; \mathrm{p}<.05)$ are found to generate significant difference by gender of teachers in
Turkey. It is determined that in Turkey, male teachers' attitudes toward the applicability of educational researches $(M=3.09)$ and attitudes toward educational researches in general $(\mathrm{M}=3.80)$ are higher than female teachers' attitudes toward the applicability of educational researches $(\mathrm{M}=2.74)$ and attitudes toward educational researches in general $(M=3.65)$. In comparing the attitudes of teachers towards educational research across cultures, one-way analysis of variance ANOVA related to age variable is given in Table 5 . 
Table 5. One-way analysis of variance (ANOVA) results related to age variable in a cross-cultural comparison of teachers for educational research

\begin{tabular}{|c|c|c|c|c|c|c|c|c|c|c|c|}
\hline & Country & Age & $\mathbf{N}$ & $\mathbf{M}$ & Sd & $\begin{array}{l}\text { Source of } \\
\text { Variance }\end{array}$ & $\begin{array}{c}\text { Sum of } \\
\text { Squares }\end{array}$ & df & $\begin{array}{c}\text { Mean } \\
\text { Square }\end{array}$ & $\mathbf{F}$ & $\mathbf{p}$ \\
\hline \multirow{10}{*}{$\frac{\alpha}{\mathbf{Z}}$} & \multirow{5}{*}{ 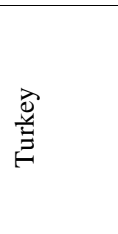 } & 30 age and under & 93 & 4,07 & ,471 & Bet. Gr. & ,325 & 3 & , 108 & \multirow{5}{*}{,605 } & \multirow{5}{*}{,612 } \\
\hline & & $31-40$ age & 34 & 4,13 & ,328 & Wit. Gr. & 31,280 & 175 & 179 & & \\
\hline & & $41-50$ age & 39 & 4,01 & ,391 & Total & 31,605 & 178 & & & \\
\hline & & $51+$ & 13 & 4,01 & ,342 & & & & & & \\
\hline & & Total & 179 & 4,06 & ,421 & & & & & & \\
\hline & \multirow{5}{*}{$\begin{array}{l}0 \\
0 \\
0 \\
0 \\
1\end{array}$} & 30 age and under & 12 & 4,07 & ,57 & Bet. Gr. & ,453 & 3 & , 151 & \multirow{5}{*}{, 861} & \multirow{5}{*}{,463 } \\
\hline & & $31-40$ age & 61 & 4,23 & ,413 & Wit. Gr. & 24,702 & 141 &, 175 & & \\
\hline & & $41-50$ age & 55 & 4,15 & ,412 & Total & 25,154 & 144 & & & \\
\hline & & $51+$ & 17 & 4,10 &, 321 & & & & & & \\
\hline & & Total & 145 & 4,17 & 417 & & & & & & \\
\hline \multirow{10}{*}{$\frac{a}{|r|}$} & \multirow{5}{*}{ 离 } & 30 age and under & 93 & 4,32 & ,453 & Bet. Gr. & , 185 & 3 & ,062 & \multirow{5}{*}{,326 } & \multirow{5}{*}{,807 } \\
\hline & & $31-40$ age & 34 & 4,24 & ,440 & Wit. Gr. & 33,116 & 175 & , 189 & & \\
\hline & & $41-50$ age & 39 & 4,26 & ,395 & Total & 33,301 & 178 & & & \\
\hline & & $51+$ & 13 & 4,20 & ,391 & & & & & & \\
\hline & & Total & 179 & 4,27 & ,432 & & & & & & \\
\hline & \multirow{5}{*}{$\begin{array}{l}0 \\
0 \\
0 \\
0 \\
1\end{array}$} & 30 age and under & 12 & 4,22 & ,533 & Bet. Gr. & ,703 & 3 & ,234 & \multirow{5}{*}{1,020} & \multirow{5}{*}{,386 } \\
\hline & & $31-40$ age & 61 & 4,42 & 450 & Wit. Gr. & 32,407 & 141 & 230 & & \\
\hline & & $41-50$ age & 55 & 4,35 &, 503 & Total & 33,110 & 144 & & & \\
\hline & & $51+$ & 17 & 4,25 & ,460 & & & & & & \\
\hline & & Total & 145 & 4,36 & ,479 & & & & & & \\
\hline \multirow{10}{*}{$\frac{\alpha}{\frac{r}{1}}$} & \multirow{5}{*}{ 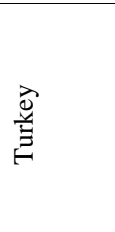 } & 30 age and under & 93 & 2,76 & ,746 & Bet. Gr. & 2,942 & 3 & ,981 & \multirow{5}{*}{1,741} & \multirow{5}{*}{, 160} \\
\hline & & $31-40$ age & 34 & 2,90 & ,786 & Wit. Gr. & 98,572 & 175 & ,563 & & \\
\hline & & $41-50$ age & 39 & 2,99 & ,774 & Total & 101,514 & 178 & & & \\
\hline & & $51+$ & 13 & 3,17 & ,589 & & & & & & \\
\hline & & Total & 179 & 2,87 & ,755 & & & & & & \\
\hline & \multirow{5}{*}{$\begin{array}{l}0 \\
0 \\
0 \\
0 \\
1\end{array}$} & 30 age and under & 12 & 2,98 & ,693 & Bet. Gr. & 2,745 & 3 & ,915 & \multirow{5}{*}{1,892} & \multirow{5}{*}{,134 } \\
\hline & & $31-40$ age & 61 & 2,63 & ,707 & Wit. Gr. & 68,181 & 141 & ,484 & & \\
\hline & & $41-50$ age & 55 & 2,55 & ,705 & Total & 70,926 & 144 & & & \\
\hline & & $51+$ & 17 & 2,88 & ,608 & & & & & & \\
\hline & & Total & 145 & 2,66 & ,701 & & & & & & \\
\hline \multirow{10}{*}{ 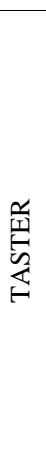 } & \multirow{5}{*}{$\underset{⿱ 亠 乂}{\stackrel{\vec{d}}{\Xi}}$} & 30 age and under & 93 & 3,68 & ,260 & Bet. Gr. & , 170 & 3 & 057 & & \\
\hline & & $31-40$ age & 34 & 3,73 & ,281 & Wit. Gr. & 13,987 & 175 & ,080 & & \\
\hline & & $41-50$ age & 39 & 3,73 & 321 & Total & 14,158 & 178 & &, 710 &, 547 \\
\hline & & $51+$ & 13 & 3,77 & ,319 & & & & & & \\
\hline & & Total & 179 & 3,71 & ,282 & & & & & & \\
\hline & & 30 age and under & 12 & 3,73 & ,278 & Bet. Gr. & ,191 & 3 & ,064 & & \\
\hline & & $31-40$ age & 61 & 3,73 & 295 & Wit. Gr. & 12,458 & 141 & ,088 & & \\
\hline & రి & $41-50$ age & 55 & 3,65 & ,296 & Total & 12,648 & 144 & &, 719 &, 542 \\
\hline & 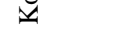 & $51+$ & 17 & 3,72 & ,318 & & & & & & \\
\hline & & Total & 145 & 3,70 & 296 & & & & & & \\
\hline
\end{tabular}

According to the results given in Table 5, it is found that there is no significant difference between teachers' attitudes toward educational research in Turkey and Kosovo by age variable in $(\mathrm{p}>0.5)$.
In comparing the attitudes of teachers towards educational research across cultures, the t-test analysis results related to the level of education are given in Table 6 . 
Table 6. The results of the t-test analysis regarding the variable of education level in comparing the attitudes of teachers towards educational

\begin{tabular}{|c|c|c|c|c|c|c|c|c|}
\hline Sub-dimensions & Culture & $\begin{array}{l}\text { Level of } \\
\text { Education }\end{array}$ & $\mathbf{N}$ & $\mathbf{M}$ & Sd & df & $\mathbf{t}$ & $\mathbf{p}$ \\
\hline \multirow{4}{*}{ NER } & \multirow{2}{*}{ Turkey } & Bachelors & 165 & 4.07 & .43 & \multirow{2}{*}{177} & \multirow{2}{*}{.53} & \multirow{2}{*}{.595} \\
\hline & & Postgraduate & 14 & 4.01 & .24 & & & \\
\hline & \multirow{2}{*}{ Kosovo } & Bachelors & 124 & 4.14 & .40 & \multirow{2}{*}{143} & \multirow{2}{*}{-2.20} & \multirow{2}{*}{.029} \\
\hline & & Postgraduate & 21 & 4.36 & .46 & & & \\
\hline \multirow{4}{*}{ VER } & \multirow{2}{*}{ Turkey } & Bachelors & 165 & 4.28 & .43 & \multirow{2}{*}{177} & \multirow{2}{*}{.97} & \multirow{2}{*}{.332} \\
\hline & & Postgraduate & 14 & 4.16 & .43 & & & \\
\hline & \multirow{2}{*}{ Kosovo } & Bachelors & 124 & 4.33 & .45 & \multirow{2}{*}{143} & \multirow{2}{*}{-1.99} & \multirow{2}{*}{.048} \\
\hline & & Postgraduate & 21 & 4.55 & .56 & & & \\
\hline \multirow{4}{*}{ APER } & \multirow{2}{*}{ Turkey } & Bachelors & 165 & 2.85 & .74 & \multirow{2}{*}{177} & \multirow{2}{*}{.71} & \multirow{2}{*}{.476} \\
\hline & & Postgraduate & 14 & 3.01 & .90 & & & \\
\hline & \multirow{2}{*}{ Kosovo } & Bachelors & 124 & 2.65 & .68 & \multirow{2}{*}{143} & \multirow{2}{*}{-.16} & \multirow{2}{*}{.866} \\
\hline & & Postgraduate & 21 & 2.68 & .82 & & & \\
\hline \multirow{4}{*}{ TASTER } & \multirow{2}{*}{ Turkey } & Bachelors & 165 & 3.71 & .28 & \multirow{2}{*}{177} & \multirow{2}{*}{.05} & \multirow{2}{*}{.956} \\
\hline & & Postgraduate & 14 & 3.70 & .28 & & & \\
\hline & \multirow{2}{*}{ Kosovo } & Bachelors & 124 & 3.68 & .29 & \multirow{2}{*}{143} & \multirow{2}{*}{-2.20} & \multirow{2}{*}{.029} \\
\hline & & Postgraduate & 21 & 3.83 & .27 & & & \\
\hline
\end{tabular}

As it is displayed in Table 6, according to the education level variable in the cultural comparison of teachers' attitudes toward educational research, in Kosovo, teachers' attitudes toward the necessity of educational research $(\mathrm{t}=-2.20 ; \mathrm{p}<.05)$, valuing educational research $(\mathrm{t}=-1.99 ; \mathrm{p}<.05)$, and attitudes toward educational research in general $(\mathrm{t}=-2.20 ; \mathrm{p}<.05)$ show a significant difference by education level variable. In Kosovo, teachers', with a postgraduate degree, attitudes toward the necessity of educational research $(M=4.36)$, valuing educational research $(M=4.55)$ and attitudes towards educational research in general $(M=4.14)$ are higher than teachers', with only a bachelors' degree, attitudes toward the necessity of educational research $(\mathrm{M}=4.14)$, valuing educational research $(\mathrm{M}=33)$ and attitudes towards educational research in general $(M=3.68)$. There is no significant difference between teachers' attitudes toward educational researches in Turkey by education level variable $(\mathrm{p}>0.5)$.

The results of one-way analysis of variance (ANOVA) regarding the professional seniority variable in cross-cultural-comparing the attitudes of teachers towards educational research are given in Table 7. 
Table 7. The results of one-way variance (ANOVA) analysis regarding the occupational seniority variable of the cross-cultural comparison of teachers' attitudes towards educational research

\begin{tabular}{|c|c|c|c|c|c|c|c|c|c|c|c|}
\hline & Country & $\begin{array}{l}\text { Occupational } \\
\text { Seniority }\end{array}$ & $\mathbf{N}$ & $\mathbf{M}$ & Sd & $\begin{array}{l}\text { Source of } \\
\text { Variance }\end{array}$ & $\begin{array}{l}\text { Sum of } \\
\text { Squares }\end{array}$ & df & $\begin{array}{r}\text { Mean } \\
\text { Square }\end{array}$ & $\mathbf{F}$ & $\mathbf{p}$ \\
\hline \multirow{12}{*}{$\frac{a}{\mathbf{Z}}$} & \multirow{6}{*}{$\underset{\Xi}{\stackrel{\overrightarrow{0}}{\Xi}}$} & 5 years and under & 96 & 4,29 &, 450 & Bet. Gr. &, 828 & 4 & ,207 & \multirow{6}{*}{1,170} & \multirow{6}{*}{,326 } \\
\hline & & 6-10 years & 11 & 4,31 &, 474 & Wit. Gr. & 30,777 & 174 &, 177 & & \\
\hline & & $11-15$ years & 17 & 4,27 & ,436 & \multirow[t]{4}{*}{ Total } & \multirow[t]{4}{*}{31,605} & \multirow[t]{4}{*}{178} & & & \\
\hline & & 16-20 years & 30 & 4,16 &, 375 & & & & & & \\
\hline & & $21+$ & 25 & 4,31 &, 417 & & & & & & \\
\hline & & Total & 179 & 4,27 & ,432 & & & & & & \\
\hline & \multirow{6}{*}{$\begin{array}{l}0 \\
0 \\
0 \\
0 \\
1\end{array}$} & 5 years and under & 24 & 4,30 & ,409 & Bet. Gr. &, 710 & 4 & , 178 & \multirow{6}{*}{1,017} & \multirow{6}{*}{, 401} \\
\hline & & 6-10 years & 38 & 4,12 & ,462 & Wit. Gr. & 24,444 & 140 &, 175 & & \\
\hline & & 11-15 years & 42 & 4,15 &, 415 & Total & 25,154 & 144 & & & \\
\hline & & 16-20 years & 23 & 4,22 &, 412 & & & & & & \\
\hline & & $21+$ & 18 & 4,11 &, 330 & & & & & & \\
\hline & & Total & 145 & 4,17 & ,417 & & & & & & \\
\hline \multirow{12}{*}{$\frac{\alpha}{\frac{1}{>}}$} & \multirow{6}{*}{$\underset{\Xi}{\stackrel{\vec{\partial}}{\Xi}}$} & 5 years and under & 96 & 2,79 &, 750 & Bet. Gr. & 485 & 4 &, 121 & \multirow{6}{*}{643} & \multirow{6}{*}{, 632} \\
\hline & & 6-10 years & 11 & 2,63 &, 569 & Wit. Gr. & 32,815 & 174 &, 189 & & \\
\hline & & 11-15 years & 17 & 3,21 &, 872 & Total & 33,301 & 178 & & & \\
\hline & & $16-20$ years & 30 & 2,97 &, 823 & & & & & & \\
\hline & & $21+$ & 25 & 2,93 &, 621 & & & & & & \\
\hline & & Total & 179 & 2,87 &, 755 & & & & & & \\
\hline & \multirow{6}{*}{$\begin{array}{l}0 \\
0 \\
0 \\
0 \\
1\end{array}$} & 5 years and under & 24 & 4,33 & ,501 & Bet. Gr. &, 224 & 4 &, 056 & \multirow{6}{*}{, 239} & \multirow{6}{*}{,916 } \\
\hline & & 6-10 years & 38 & 4,36 & ,496 & Wit. Gr. & 32,886 & 140 &, 235 & & \\
\hline & & 11-15 years & 42 & 4,36 &, 467 & Total & 33,110 & 144 & & & \\
\hline & & 16-20 years & 23 & 4,44 & ,496 & & & & & & \\
\hline & & $21+$ & 18 & 4,30 & ,461 & & & & & & \\
\hline & & Total & 145 & 4,36 & ,479 & & & & & & \\
\hline \multirow{12}{*}{$\frac{a}{\frac{\pi}{2}}$} & \multirow{6}{*}{$\underset{\Xi}{\stackrel{\Xi}{\Xi}}$} & 5 years and under & 96 & 2,79 &, 750 & Bet. Gr. & 3,610 & 4 & ,903 & \multirow{6}{*}{1,604} & \\
\hline & & 6-10 years & 11 & 2,63 &, 569 & Wit. Gr. & 97,904 & 174 &, 563 & & \\
\hline & & 11-15 years & 17 & 3,21 &, 872 & Total & 101,514 & 178 & & & 175 \\
\hline & & 16-20 years & 30 & 2,97 &, 823 & & & & & &, 175 \\
\hline & & $21+$ & 25 & 2,93 &, 621 & & & & & & \\
\hline & & Total & 179 & 2,87 &, 755 & & & & & & \\
\hline & & 5 years and under & 24 & 2,57 &, 725 & Bet. Gr. & 1,726 & 4 & ,432 & & \\
\hline & & 6-10 years & 38 & 2,76 &, 736 & Wit. Gr. & 69,199 & 140 & ,494 & & \\
\hline & 3 & 11-15 years & 42 & 2,57 &, 684 & Total & 70,926 & 144 & & 873 & 482 \\
\hline & $\overbrace{0}^{\infty}$ & 16-20 years & 23 & 2,60 &, 770 & & & & & 20/J & \\
\hline & & $21+$ & 18 & 2,85 &, 527 & & & & & & \\
\hline & & Total & 145 & 2,66 & ,701 & & & & & & \\
\hline & & 5 years and under & 96 & 3,689 &, 263 & Bet. Gr. & ,605 & 4 &, 151 & & \\
\hline & & 6-10 years & 11 & 3,69 &, 181 & Wit. Gr. & 13,553 & 174 & ,078 & & \\
\hline & ऐ & 11-15 years & 17 & 3,88 & ,349 & Total & 14,158 & 178 & & 1942 & 106 \\
\hline$\simeq$ & 总 & 16-20 years & 30 & 3,68 &, 300 & & & & & 1,942 &, 100 \\
\hline 凰 & & $21+$ & 25 & 3,73 & ,291 & & & & & & \\
\hline$\overleftarrow{E}$ & & Total & 179 & 3,71 & ,282 & & & & & & \\
\hline & 0 & 5 years and under & 24 & 3,70 & ,274 & Bet. Gr. &, 102 & 4 & ,025 & & \\
\hline & 0 & 6-10 years & 38 & 3,71 & ,319 & Wit. Gr. & 12,546 & 140 & ,090 &, 284 &, 888 \\
\hline & 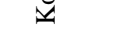 & 11-15 years & 42 & 3,66 &, 276 & Total & 12,648 & 144 & & & \\
\hline
\end{tabular}




\begin{tabular}{lccc}
\hline $16-20$ years & 23 & 3,72 &, 334 \\
$21+$ & 18 & 3,73 &, 290 \\
Total & 145 & 3,70 &, 296 \\
\hline
\end{tabular}

As shown in Table 7, it is found that there is no significant difference between teachers' attitudes toward educational research in Turkey and Kosovo by occupational seniority variable $(\mathrm{p}>0.5)$.
The results of one-way analysis of variance (ANOVA) regarding the graduate department variable in which teachers' attitudes towards educational research are compared across-cultures are given in Table 8 .

Table 8. The results of one-way variance (ANOVA) analysis regarding the graduate department variable of the cross-cultural comparison of teachers' attitudes towards educational research

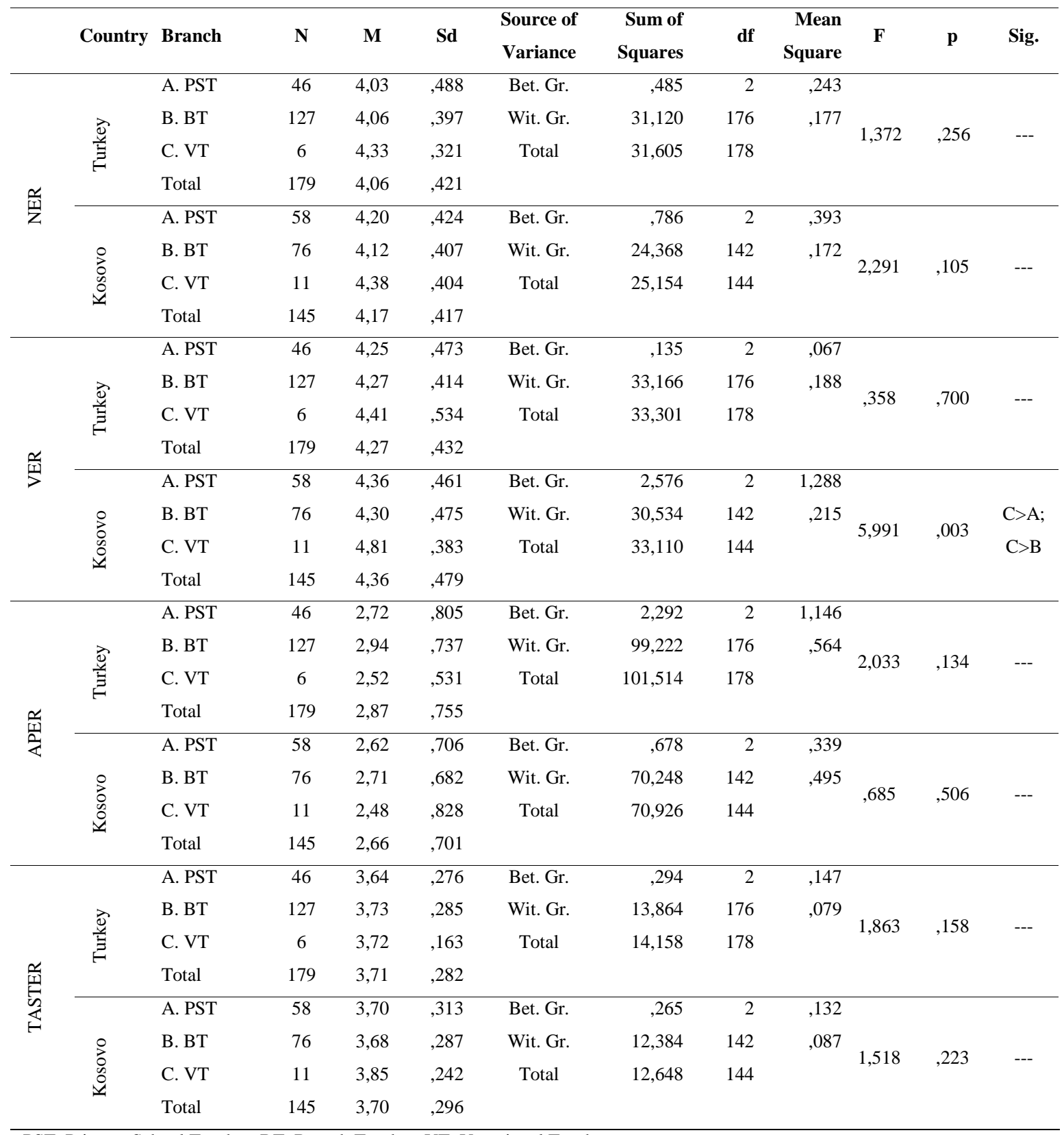

PST: Primary School Teacher, BT: Branch Teacher, VT: Vocational Teacher 
As can be seen in Table 8 , as a result of the cross-cultural comparison of the attitudes of teachers in Kosovo to educational research, the attitudes of teachers in Kosovo to valuing educational research were significantly different compared to the branches they graduated from $(\mathrm{p}<.05)$. As a result of the analysis made to determine which groups are different, the teachers who work as vocational teachers $(M=4.81)$ in Kosovo have higher attitudes towards educational research than both classroom teachers $(M=4.36)$ and branch teachers $(M=4.30)$. However, in other dimensions, teachers' attitudes toward educational research do not show significant differences according to the branches they graduated from in both countries $(\mathrm{p}>.05)$.

In comparing the attitudes of teachers towards educational research across cultures, one-way analysis of variance (ANOVA) related to school type variable is given in Table 9.

Table 9. The results of one-way variance (ANOVA) analysis regarding the school type variable of the comparison of the attitudes of teachers towards educational research across cultures

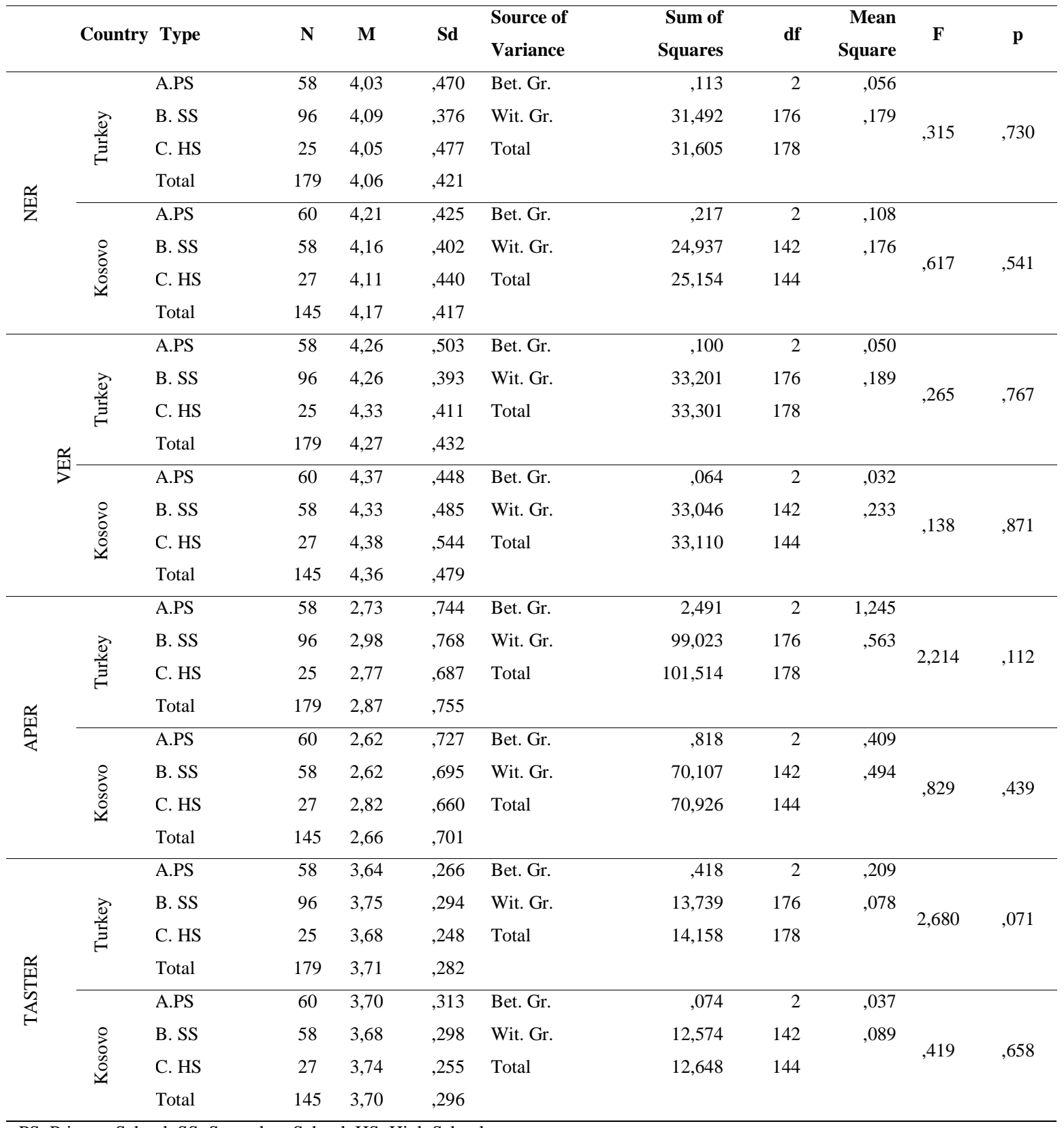

PS: Primary School, SS: Secondary School, HS: High School 
As shown in Table 9, it is found that there is no significant difference between teachers' attitudes toward educational research in Turkey and Kosovo by school type variable ( $p>0.5$ ).

\section{Discussion and Conclusions}

Considering the idea that teachers are affected by the use of research findings and using these findings in their educational applications, it is decided to conduct a cross-cultural comparison of teachers' attitudes toward educational research in Turkey and Kosovo. According to the findings obtained in the study of crosscultural comparisons of teachers' attitudes towards educational research in Turkey and Kosovo, it is discovered that teachers' attitudes toward educational research, in general, are at a very "high" level. In addition, the attitudes of teachers in both countries towards the necessity of educational research are at a "high" level, while their attitudes towards valuing educational research are at a "very high", and their attitudes towards the applicability of educational research are at a "moderate" level. According to this result, it can be said that teachers believe in the necessity of educational research because they need this research and they value educational research to reach knowledge arising from reasons related to this need. Interestingly, the applicability of educational research is perceived less. In line with the findings of this research, Nagra and Kaur (2013) stated that teacher educator's/education faculty members/academicians in India; Short and Szabo (1974) in America (New York) and Johnson (1966) in England (London) determined that teachers' attitudes towards educational research are very positive and high. Sekerci, Ilhan, Sozbilir and Yildirim (2017) and Gül and Özay Kose (2017) in their research in Turkey, determined that teachers' attitudes towards education research in general and the necessity of educational research are "high"; their attitudes towards valuing educational research are "very high"; and their attitudes towards the applicability of educational researches were "low". According to the findings of the study conducted by Karakaya (2015), teachers see educational researches as a tool for occupational development. However, again, according to the results of this research, teachers find educational researches important in terms of bringing appropriate solutions to the problems in the class, increasing awareness in educational activities, supporting teacher autonomy, increasing collaboration among colleagues and being a feedback tool by reflecting student perspectives. However, they stated that although the attitudes of teachers towards educational research were mostly positive, they experienced difficulties in the implementation process. Kahraman and Köleli (2017) reported that teachers' attitudes towards educational research were above average, while Korkmaz et al. (2011) reported high levels. However, as a result of research, it is revealed that teachers do not show enough interest in scientific researches in their schools (Sarı, 2006). İlhan et al. (2016) found that students' attitudes towards research were "low" in their study on associate-degree and undergraduate students who took research methods courses at 6 different universities. However, according to the results of the research conducted by Isakson and Ellsworth (1978) the education given to the students improves the research education by affecting the attitudes towards the research positively. It is an interesting finding that the attitudes of teachers in service towards educational research as "high" and the attitudes of university students towards research as a "low" level. The difference of this situation may be due to the fact that while the university students develop their attitudes towards researches with theoretical knowledge, while the teachers have both received similar education and are now in the application process. Theoretical knowledge becomes more important and valuable when applied and benefited. It is their duty to carry out this process since they are teachers who apply theoretical knowledge (Aylar, 2017). In the implementation of researches believed and valued, the teacher must fulfill his duty. The most important feature that distinguishes the teaching occupation from other occupations is that it requires more labor. The title of the educator is getting stronger in the application process (Batur and Balc1, 2013). Therefore, teachers should face problems related to research practices in education, evaluate themselves and overcome this problem. In order to be able to value and apply the educational research they believe is necessary, they must improve themselves and follow lifelong learning and fulfill their responsibilities related to their profession (Demiraslan and Usluel, 2008). The purpose of education systems is the structuring of societies made up of individuals who research, question, think critically and emphasize creativity. Teachers play a leading role in the realization of this task. If teachers are devoid of research skills and research practices, they cannot be expected to acquire research culture in their educated people (Ministry of National Education [MoNE], 2008; Sarı, 2006). We can talk about the existence of the same results in research on the subject (Akçöltekin, 2017; Delihasan, 2019). These results are a positive value for both cultures in the information age we live in and can be considered promising for their future. The fact that educational research is considered to be interculturally accepted, considered positive and important may increase the quality of education in a private sense and contribute to the success of education systems in general.

As a result of analysis conducted for the main purpose of the research, while teachers', in Kosovo, attitudes toward the necessity of educational research are higher/positive than teachers' attitudes in Turkey, teachers', in Turkey, attitudes toward the applicability of educational researches are higher/ positive than teachers in Kosovo. In other words, teachers in Kosovo believe in the necessity of educational researches, the 
teachers in Turkey believe in the applicability of this researches more. This result can be explained by the development, economic situation or cultural values of the countries. Education has goals such as ensuring the continuity and development of society. Therefore, their attitude may be more positive, as teachers in Kosovo believe that education research is necessary as an element that enhances education. When evaluated from a cultural point of view, it can be interpreted differently. Each culture has its own characteristics (Ünlü et al., 2016). Culture, as the common qualities of individuals in a community, are lifestyles that are transferred and shared from individual to individual (Aytaç, 2006; Triandis, 1994). The meanings that societies attach to their lives are parallel to the culture of the environment they live in (Barker and Jane, 2016). Community culture consists of values and assumptions. The values that make up culture are the interests of a society that tend to prefer certain situations more than others (Hofstede et al., 2010). Teachers in Kosovo value the necessity of educational researches, while teachers in Turkey can give more value to the applicability of the findings obtained from educational researches. Therefore, it can be said that there is a significant difference in teachers' attitudes towards the necessity and applicability of educational research in the cross-cultural comparison dimension.

According to the findings obtained in the study of comparing attitudes towards educational research between cultures, male teachers' attitudes in Turkey toward educational research in general and applicability of educational research are higher/more positive than of female teachers. The attitudes of teachers in Kosovo towards educational research do not differ significantly according to their gender. Nagra and Kaur (2013) in India, Short and Szabo (1974) in America, Shaukat et al. (2014), and Beycioğlu, Özer and Teyar Uğurlu (2009) in Turkey assessed that there is not a significant difference between male and female teachers' opinions regarding educational research and their attitudes are at a similar level. However, Erdamar and Akpunar (2017) determined that male teachers have more positive thoughts about educational research than female teachers. In Johnson's (1966) study in the UK (London), and Kahraman and Köleli's (2017) research in Turkey, they concluded that teachers' attitudes towards educational research are higher than that of women. The authors stated that the reason for this difference is a research subject that needs to be answered. However, when other research results in the literature are examined, it is understood that the results are not consistent. While some studies show significant differences in the attitudes of men and women's attitudes towards educational research (Kahraman and Köleli, 2017; Korkmaz et al., 2011; Sekerci et al., 2017; Polat, 2014), while others do not (Beycioğlu et al., 2009; Bibi et al., 2012; Biçer et al., 2013; Gül and Özay Köse, 2017; Kotan, 2019; Uçgun and Ünal, 2015;
Sadıç, 2019; Yenilmez and Ata, 2012). In this context, it would be appropriate to state that the findings regarding the gender variable are not consistent in studies conducted for educational research.

According to the cross-cultural comparison of teachers' attitudes toward educational research by education level variable, teachers who have a postgraduate degree in Kosovo have more positive attitudes towards the necessity of educational researches, valuing educational researches and education research in general. It is noteworthy that their attitudes towards the applicability of educational research do not differ in terms of their bachelors' and postgraduate degrees. Education levels of teachers in Turkey are not creating differences in their attitudes towards educational researches. In Turkey, in Uçgun and Ünal's (2015) study on Turkish and classroom teachers, Kotan's (2019) study on music teachers and Sekerci et al. (2017) study on teachers graduated from 12 different branches, it is put forward that teachers' attitudes towards educational research did not differ significantly from their educational background. On the other hand, İhan et al. (2016) found that associate degree students showed more interest in research, attach importance, are motivated and have higher anxiety than undergraduate students. When the literature is examined, it was stated in the similar studies that the teachers who follow the educational researches have difficulties in understanding the educational researches and cannot use it enough in their professional lives (İlhan et al., 2013; Sadıç, 2019). It can be said that there is a meaningful difference in the attitudes of teachers in Kosovo, who have postgraduate education, towards educational research, in fact, it can be said that the aim of graduate education is fulfilled and raised awareness on teacher's attitudes toward educational researches.

In comparing the attitudes of teachers towards educational research across cultures, in Kosovo, attitudes of vocational teachers towards educational research are more positive/ higher than primary school teachers and branch teachers. As one of the reasons for this, it can be said that vocational teachers give more value to educational researches to renew themselves and to follow developments in their professions closely. According to the results of Short and Szabo (1974) in the USA, the attitudes of social studies teachers towards educational research are lower than teachers of English, Science, Mathematics, and other branches. In Turkey, Sahin and Arcagök (2013) revealed that branch teachers making research more frequent than primary school teachers. In his study, Polat (2014) found that the positive attitudes of university students studying in the Turkish teaching department towards educational researches are lower than those of the mathematics department students. However, in the study of Korkmaz et al. (2011), they determined that in the positive 
attitudes of the education faculty students towards the research their department does not constitute a significant difference. Similarly, Gül and Özay Köse (2017) demonstrated that in the attitudes of science and mathematics teachers toward researches, the branch variable does not create a significant difference. As a different school level, Nagra and Kaur (2013) found that science and art teacher educators/academics/members of education faculty have similar attitudes towards research in India. However, it was seen that teachers in all branches showed positive attitudes towards educational research and similar results were obtained (Ekiz, 2006; Sekerci et al., 2017; Uçgun and Ünal, 2015; Yıldırım et al., 2017). Based on these results, it can be said that the attitudes of teachers in all branches towards educational research are positive, but the attitudes of teachers in mathematics and science towards higher education research are higher.

According to the research findings, no significant difference was found in the cross-cultural comparison of teachers' attitudes towards educational research about age, professional seniority, and school type. There are studies in the literature that determine the attitudes of teachers towards educational research do not differ according to their seniority (Beycioğlu et al., 2009; Byman, 2009; Ekiz, 2006; Johnson, 1966; Short and Szabo, 1974; Sekerci et al., 2017; Uçgun and Ünal, 2015) as well as studies showing significant difference by seniority variable (Akcöltekin et al., 2017). However, the findings of studies conducted in different countries show that there is a difference according to the variable of seniority. For instance, in Turkey, studies made by Akcöltekin et al. (2017) with Erdamar and Akpunar (2017), demonstrate those beginning teachers' and teachers with occupational seniority under 10 years' attitudes toward educational research are more positive than teachers with occupational seniority above 10 years. Johnson (1966) in England and Stamou, Humphreys and Schmidt (2006) in their experimental studies in Greece, have developed more positive attitudes towards education research compared to teachers who have not previously participated in educational research. Similarly, researches reporting that the attitudes of teachers under the age of 25 towards the applicability of educational researches are higher than those of the teachers who are 26-30 years old, but their attitudes toward the necessity of educational research and their attitude towards valuing do not differ according to their age (Kotan, 2019). Contrary to Kotan's (2019) research findings, Shaukat et al. (2014) found that the positive attitudes of teachers 30 years old and older towards educational research are more positive than teachers under 30 years old. In this study, it is concluded that the teachers who work in different school types have similar attitudes towards educational research. Johnson (1966) also found that teachers at primary and secondary levels have similar attitudes towards educational research. In this context, we can state that the variables of age, professional seniority and school type of teachers working in different cultures do not affect their attitudes towards educational research.

As a general conclusion of this study, it is discovered teachers', in Kosovo and Turkey, attitudes toward educational research are high. However, it is recommended that qualitative researches be carried out in-depth, which particularly examines why their attitude towards the applicability of research findings is low. In addition, it can be recommended to conduct applied training and workshops in order to develop teachers' attitudes toward educational research for in pre-service teacher education, academics, in-service career periods, decision-makers, policymakers and school administrators in the education system and the provision of appropriate conditions/equipment for the applicability of the findings from educational research. The involvement of teachers in the research provides a positive attitude towards research (Johson, 1966). Therefore, the participation of teachers in educational research can be encouraged and carried out in such a way that their participation can be ensured.

\section{References}

1. Akçöltekin, A., Engin, A. O., \& Sevgin, H. (2017). Attitudes of high school teachers to educational research using classification-tree method, Eurasian Journal of Educational Research, 68, 19-47. http://dx.doi.org/10.14689/ejer.2017.68.2

2. Akçöltekin, A. (2017). Lise öğretmenlerinin bireysel yenilikçilik algıları ile eğitim araştırmalarına yönelik tutumları arasındaki ilişkinin incelenmesi. [Examining the relationship between high school teachers' perceptions of individual innovation and their attitudes towards educational research]. Eğitim Kuram ve Uygulama Araştırmaları Dergisi, 3(1), 23-37, Retrieved from

https://dergipark.org.tr/en/pub/ekuad/issue/28620/311129

3. Auger, W. \& Wideman, R. (2000). Using action research to open the door life-long professional learning.

Education, 121(1), 120-127, Retrieved from http://web.a.ebscohost.com/ehost/pdfviewer/pdfviewer?v $\mathrm{id}=0 \& \mathrm{sid}=3 \mathrm{f} 9 \mathrm{dd} 80 \mathrm{f}-\mathrm{ed} 3 \mathrm{f}-4 \mathrm{~d} 4 \mathrm{~d}-\mathrm{a} 795$ a3250c5ff48e\%40sdc-v-sessmgr01

4. Aydın, İ. (2016). Eğitim ve öğretimde etik [Ethics in education and training]. Ankara: Pegem.

5. Aylar, E. (2017). Sınıf öğretmeni yetiştirme sürecinde problem çözmeye dair pedagojik alan bilgisine ilişkin çıkarımlar. [Implications for pedagogical content knowledge related to problem solving in the classroom teacher training process]. Mersin Üniversitesi Eğitim 
Fakültesi Dergisi, 13(2), 744-759.

https://doi.org/10.17860/mersinefd.312232

6. Aytaç, Ö. (2006). Girişimcilik: Sosyokültürel bir prespektif. [Entrepreneurship: A Socio-Cultural Perspective]. Dumlupınar Üniversitesi Sosyal Bilimler Dergisi, 15, Retrieved from https://dergipark.org.tr/tr/pub/dpusbe/issue/4757/65345

7. Barker, C., \& Jane, E. A. (2016). Cultural studies: Theory and practice (5th. edition). London: Sage.

8. Başaran, İ. E. (1994). Eğitime giriş. [Introduction to education]. Ankara: Kadıoğlu.

9. Batur, Z., \& Balcı, S. (2013). Türk öğretmenlerinin pedagojik alan incelenmesi. [Pedagogical study of Turkish teachers]. Ana Dili Eğitimi Dergisi, 1(2), 9-19. https://doi.org/10.14520/adyusbd.468

10. Beycioğlu, K., Ozer N, \& Teyar Uğurlu, C. (2009). Teachers' views on educational research. Teaching and Teacher Education ,26, 1088-1093. https://doi.org/10.1016/j.tate.2009.11.004

11. Bibi, F., Lqbal, H. M., \& Majid, N. (2012). Attitude of prospective teachers towards research: implications for teacher education in Pakistan. Contemporary Educational Researches Journal, 2(1), 8-14. Retrieved from http://archives.unpub.eu/index.php/cerj/article/view/952/ pdf 115

12. Biçer, M., Bozkırlı, K. Ç., \& Er, O. (2013). Türkçe öğretmeni adaylarının bilimsel araştırmaya yönelik tutumlarının değerlendirilmesi. [Evaluation of Turkish teacher candidates' attitudes towards scientific research]. Atatürk Üniversitesi Türkiyat Araştırmaları Dergisi, 50, 327-342. Retrieved from https://dergipark.org.tr/tr/pub/deubefd/issue/46964/43547

13. Bilhan, S. (1991). Eğitim felsefesi [Education philosophy]. Ankara: A.Ü. Eğitim Fakültesi Yayınları.

14. Boehm, A. E. (1982). Assessment of basic concepts. In D. Paget ve B. A. Bracken (Ed.). The psychoeducational assessment of preschool children (s. 145-116). New York: Grune \& Stratton.

15. Butt, I. H., \& Shams, J. A. (2013). Master's in education student attitudes towards research: A comparison between two Public Sector Universities in Punjab. A Research Journal of South Asian Studies, 28(1), 97-105, Retrieved from

http://journals.pu.edu.pk/journals/index.php/IJSAS/articl e/viewFile/2870/1116

16. Büyüköztürk, Ş. Çakmak, Kılıç, E., Akgün, Ö.E., Karadeniz, Ş., \& Demirel, F. (2014). Bilimsel araştırmalar yöntemleri [Scientific research methods]. Ankara: Pegem.
17. Byman, R., Krokfors, L., Toom, A., Maaranen, K., Jyrhämä, R., Kynäslahti, H., \& Kansanen, P. (2009) Educating inquiry-oriented teachers: students' attitudes and experiences towards research-based teacher education, Educational Research and Evaluation, 15(1), 79-92. https://doi.org/10.1080/13803610802591808

18. Can, A. (2014). SPSS ile bilimsel araştırma sürecinde nicel veri analizi [Quantitative data analysis in scientific research process with SPSS]. Ankara: Pegem.

19. Cohen, L., Manion, L., \& Morrison, K. (2007). Research methods in educations. New York: Routledge.

20. Creswell, J. V. (2017). Eğitim araştırmaları nicel ve nitel araştırmalarının planlanması, yürütülmesi ve değerlendirilmesi [Planning, conducting, and evaluating educational research quantitative and qualitative research] (H. Ekşi, Çev. /Trans.). İstanbul: Edam.

21. Delihasan, S. (2019). Sosyal bilgiler öğretmenlerinin eğitim araştırmalarına yönelik tutum ve görüşlerinin çeşitli değişkenler açısından incelenmesi [Investigation of social studies teachers' attitudes and opinions towards educational research in terms of various variables] (Unpublished- master thesis). Recep Tayyip Erdoğan Üniversitesi Sosyal Bilimler Enstitüsü, Rize. Retrieved from https://tez.yok.gov.tr/UlusalTezMerkezi/

22. Demiraslan, Y., \& Uslueul, Y. K. (2008). ICT Intergration processes in Turkish schools: Using activity teory to stady issues and contradictions. Australasian Journal of Education Technology, 24(4), 458-474. https://doi.org/10.14742/ajet.1204

23. Demirel, Ö. (2003). Eğitim sözlüğü [Education dictionary]. Ankara: Pegem.

24. Drill, K, Miller, S., \& Behrstock- Sherratt, E. (2012). Teachers' perspectives on educational research. Naperville, IL: American Institudes for Research.

25. Ekiz, D. (2006). Sınıf öğretmenlerinin eğitim araştırmalarına karşı tutumları [Classroom teachers' attitudes towards educational research]. Kuram ve Uygulamada Eğitim Bilimleri, 6(2), 373-394. Retrieved from http://oldsite.estp.com.tr

26. Erdamar, F. S., \& Akpunar, B. (2017). Sinıf öğretmenlerinin eğitim arastırmalarına yönelik algısı: Metaforik bir çalısma [Perception of primary teachers towards educational research: A metaphorical study]. Elektronik Eğitim Araştırmaları Dergisi, 6(11), 34-48. Retrieved from https://dergipark.org.tr/en/pub/ejedus/issue/28994/31001 $\underline{9}$

27. Ergün, M. (1994). Eğitim sosyolojisi [Education sociology]. Ankara: Ocak Yayınları. 
28. Ertürk, S. (1994). Eğitimde program geliştirme [Program development in education]. Ankara: Meteksan.

29. Everton, T., Galton, M., \& Pell, T. (2002). Educational research and the teacher. Research Papers in Education, 17(4), 373-401. https://doi.org/10.1080/0267152022000031388

30. Fidan, N., \& Erden, M (1986). Eğitim bilimine giriş. [Introduction to education science]. Ankara: Kadıoğlu.

31. Fraenkel, J. R., \& Wallen, N. E. (2006). How to design and evaluate research in education. Boston: McGrawHill.

32. Gökalp, Z. (1992). Terbiyenin kültürel ve sosyal temelleri. [Cultural and social foundations of education]. İstanbul: Milli Eğitim Basımevi.

33. Gül, Ş., \& Özay Köse, E. (2017). Fen ve matematik öğretmenlerinin eğitim araştırmalarına yönelik tutumları. [Science and mathematics teachers' attitudes towards educational research]. Yüzüncü Y1l Üniversitesi Eğitim Fakültesi Dergisi,14(1), 700-725. Retrieved from https://dergipark.org.tr/tr/pub/yyuefd/issue/28496/340313

34. Hattie, J. (2012). Visible learning for teachers: Maximizing 1mpact on learning. Retrieved from http://www.tdschools.org/wpcontent/uploads/2013/08/The+Main+Idea++Visible+Learning+for+Teachers+-+April+2013.pdf

35. Hennessy, J., \& Lynch, R. (2018). Straddling the marshy divide: exploring pre-service teachers' attitudes towards teacher research. Educational Review. https://doi.org/10.1080/00131911.2018.1459482

36. Hofstede, G., Hofstede, G. J., \& Minkov, M. (2010). Cultures and organizations: Software of the mind. New York: McGraw-Hill.

37. Hoshmand, L. L. (1991). Clinical inquiry as scientific training. Journal of Counseling-Psychologist, 19(3), 431453. https://doi.org/10.1177/0011000091193011

38. Hoy, W. K., \& Miskel, C. G. (2015). Eğitim yönetimi: Teori, araştırma ve uygulama [Educational administration: Theory research and practice] (S. Turan, Çev. / Trans.). Ankara: Nobel.

39. Isakson, R. L., \& Ellsworth, R. (1978) Teachers' attitudes toward educational research: It is time for a change. The Teacher Educator, 14(2), 9-13. https://doi.org/10.1080/08878737809554696

40. İlhan, A., Çelik, H. C., \& Arslan, A. (2016). Evaluating the attitudes of university students about scientific research. İnönü Üniversity Journal of the Faculty of Education, 17(2), 141-156. https://doi.org/10.17679/iuefd.17218132

41. İlhan, N., Şekerci, A.R., Sözbilir, M., \& Yıldırım, A. (2013). Eğitim araştırmalarına yönelik öğretmen tutum ölçeğinin geliştirilmesi: Geçerlik ve güvenirlik çalışması [Developing teacher attitude scale for educational research: Validity and reliability study]. Batı Anadolu Bilimleri Dergisi, 4(8), 31-56, Retrieved from https://dergipark.org.tr/tr/pub/baebd/issue/3335/46212

42. Johnson, M. (1966) teachers' attitudes to educational research. Educational Research, 9(1), 74-79. https://doi.org/10.1080/0013188660090113

43. Kahraman, S., \& Köleli, E. (2013). Öğretmenlerin eğitim araştırmalarına yönelik tutumlarının incelenmesi.

[Examining the attitudes of teachers towards educational research]. Bayburt Eğitim Fakültesi Dergisi,12(23), 3555, Retrieved from https://dergipark.org.tr/tr/pub/befdergi/issue/30012/2849 49

44. Kara, Y. (2017). Eğitimde sınırsız araştırma ve bilimsel yöntem [Unlimited research and scientific method in education]. Sınırsız Eğitim ve Araştırma Dergisi, 2(1), 35-47. https://doi.org/10.29250/sead.297774

45. Karakaya, N. (2015). A qualitatıve case study of english language teachers' views towards teacher research as a professional development tool (Master Thesis). Middle East Technical University, Ankara. Retrieved from https://tez.yok.gov.tr/UlusalTezMerkezi/

46. Korkmaz, Ö., Şahin, A., \& Yeşil, R. (2011). Öğretmen adaylarının bilimsel araştırmalarına yönelik tutumları [Pre-service teachers' attitudes towards scientific research]. International Online Journal of Educational Sciences, 3(3), 1169-1194. Retrieved from https://dergipark.org.tr/en/download/article-file/317283

47. Kotan, T. (2019). Müzik öğretmenlerinin eğitim araştırmalarına yönelik tutumlarının farklı değişkenler açısından incelenmesi [The attitudes of music teachers towards educational research in terms of different variables] (Master Thesis). Atatürk Üniversitesi, Erzurum. Retrieved from https://tez.yok.gov.tr/UlusalTezMerkezi/

48. Linden, W., Bakx, A., Ros, A., Beijaard, D., \& Bergh, L. (2015). The development of student teachers'research knowledge, beliefs and attitude. Journal of Education for Teaching, 41(1), 4-18. https://doi.org/10.1080/02607476.2014.992631

49. Marshall, G. (1999). Sosyoloji sözlüğü. [Sociology dictionary]. (O. Akınhay, ve D. Kömürcü, Çev. / Trans.) Ankara: Bilim ve Sanat Yayınları.

50. McMillan, J. H., and Schumacher, S. (2006). Research in education: Evidence based inquiry (6th ed.). New York: Pearson Education.

51. Ministry of National Education [MoNE] (2008). Özel alan yeterlilikleri, öğretmen yetiştirme ve genel 
müdürlüğ̈̈ [Special field competencies, teacher training and general directorate]. Ankara: MEB Yayınları.

52. Morgan, C. T. (2013). Psikolojiye giriş [Introduction to physchology] (S. Karakaş ve R. Eski, Çev. Ed. / Trans.). Konya: Eğitim Yayınevi.

53. Muthuswamy, P., Vanitha, R., Suganthan, C., \& Ramesh, P. S. (2017). A study on attıtude towards research among the doctoral students. International Journal of Civil Engineering and Technology, 8(11), 811-823. Retrieved from

http://www.iaeme.com/MasterAdmin/Journal_uploads/IJ CIET/VOLUME 8 ISSUE 11/IJCIET 08_11 083.pdf

54. Nagra, V., \& Kaur, R. (2013). Attitude of teacher educators towards research. Indian Streams Research Journal, 2(12), 1-6. https://doi.org/10.5958/j.23215771.2 .2 .003

55. Özdamar, K. (2003). Modern bilimsel araştırma yöntemleri [Modern scientific research methods]. Eskişehir: Kaan.

56. Petty, R. E., Fabrigar, L. R., \& Wegener, D. T. (2003). Emotional factors in attitudes and persuasion. Handbook of affective sciences, 752-772.

57. Plotnik, R. (2009). Psikolojiye giriş [Introduction to physchology] (T. Geniş, Çev. / Trans.). İstanbul: Kaknüs.

58. Polat, M. (2014). Eğitim fakültesi öğrencilerinin bilimsel araştırmaya yönelik tutumları. Pamukkale Üniversitesi Sosyal Bilimler Enstitüsü Dergisi, 18, 77-90. Retrieved from

https://dergipark.org.tr/tr/pub/pausbed/issue/34738/38412 $\underline{3}$

59. Sadıç, T. (2019). Lise öğretmenlerinin bireysel yenilikçilik algıları, eğitim araştırmalarına yönelik tutumları ile araştırma yeterlilikleri arasındaki ilişki (Yayımlanmamış yüksek lisans tezi). Yıldız Teknik Üniversitesi, İstanbul. Retrieved from https://tez.yok.gov.tr/UlusalTezMerkezi/

60. Sarı, M. (2006). Araştırmacı öğretmen: Öğretmenlerin bilimsel araştırmaya ilişkin görüşlerinin incelenmesi. Kuram ve Uygulamada Eğitim Bilimleri, 6(3), 847-887, Retrieved from http://oldsite.estp.com.tr/

61. Stacey, M. (1969). Methods of social research. Oxford: Pregamon.

62. Şahin, A., \& Arcagök, S. (2013). İlköğretim öğretmenlerin eğitim araştırmalarına yönelik yaklaşımları. Bilgisayar ve Eğitim Araştırmaları Dergisi, 1(2), 1-20. Retrieved from https://dergipark.org.tr/tr/pub/jcer/issue/18614/196493

63. Shaukat, S., Siddiquah, A., Abiodullah, M., \& Akbar, R. A. (2014). Postgraduate Students' Attitudes towards Research. Bulletin of Education and Research, 36(1),
111-122. Retrieved from

https://files.eric.ed.gov/fulltext/EJ1210436.pdf

64. Short, B. G., \& Szabo, M. (1974). Secondary school teachers' knowledge of and attitudes toward educational research. The Journal of Experimental Education, 43(1), 75-78. https://doi.org/10.1080/00220973.1974.10806307

65. Stamou, L., Humphreys, J. T., \& Schmidt, C. P. (2006). The effects of instruction on self-assessed research knowledge, ability, and interest among Greek music educators. Music Education Research, 8(2), 175-189. https://doi.org/10.1080/14613800600779600

66. Sekerci, A. R., Ilhan, N., Sozbilir, M., \& Yildirim, A. (2017). Science and technology teachers' attitudes towards educational research in Turkey. In Asia-Pacific Forum on Science Learning \& Teaching, 18(1). Retrieved from https://www.eduhk.hk/apfslt/v18_issue1/sekerci/index.ht $\underline{\mathrm{m} \# \mathrm{con}}$

67. Triandis, H. C. (1994). Culture and social behavior. New York: McGraw -Hill.

68. Uçgun, D., \& Ünal, E. (2015). Türkçe ve Sınıf öğretmenlerinin eğitim araştırmalarına yönelik tutumlarının incelenmesi [Investigation of Turkish and classroom teachers' attitudes towards educational research]. Erzincan Üniversitesi Sosyal Bilimler Enstitüsü Dergisi, 2, 85-94, Retrieved from https://dergipark.org.tr/en/download/article-file/715425

69. Ünlü, İ., Ilgaz, S., \& Örten, H. (2016). İlköğretim öğretmen adaylarının kültür algılarının kültür alt boyutlarına göre incelenmesi [Examination of classroom teacher candidates' cultural perceptions according to culture sub-dimensions]. Mustafa Kemal Üniversitesi Sosyal Bilimler Dergisi, 13(33), 168-177. Retrieved from https://dergipark.org.tr/tr/pub/mkusbed/issue/19579/2088 $\underline{08}$

70. Yenilmez, K., \& Ata, A. (27-30 haziran 2012). Matematik öğretmeni adaylarının bilimsel araştırmalarına yönelik tutumlarının incelenmesi. [Investigation of mathematics teacher candidates' attitudes towards scientific research]. X. Ulusal Fen Bilimleri ve Matematik Eğitim Kongresi, Bildiri e- kitabı, Niğde Üniversitesi, Niğde.

71. Yıldırım, A., \& Şimşek, H. (2018). Sosyal bilimlerde nitel araştırma yöntemleri. [Qualitative research methods in social sciences]. Ankara: Seçkin.

72. Yıldırım, A., İlhan, N., Şekerci, A. R., \& Sözbilir, M. (2013). Fen ve teknoloji öğretmenlerinin eğitim araştırmalarını takip etme, anlama ve uygulamalarda kullanma düzeyleri: Erzurum ve Erzincan örneği [Levels of science and technology teachers to follow, understand 
and use educational research: Erzurum and Erzincan

cases]. Kastamonu Eğitim Dergisi, 22(1), 81-100.

\section{Retrieved from}

https://dergipark.org.tr/tr/pub/kefdergi/issue/22603/2415

$\underline{19}$

73. Zeulli, J. S. (1994). How do teachers understand when

they read it? Teaching and Teacher Education, 10(1), 39-

55. https://doi.org/10.1016/0742-051X(94)90039-6 